\title{
Vegetation of the Dry Prairie
}

\author{
by K. F. Best, Swift Current
}

In this issue we are going to look at two members of the Compositae that are associated with the more exposed slopes of the dry prairies. These are the gumweeds and the broomweeds.

The gumweeds compose a group of annual or perennial herbs that are native to western North and South America. The genus Grindelia was named in honor of David Hieronymus Grindel, a Russian professor and botanical author. The resinous character of many of the species has given rise to such common names as gumweed, gumplant and resinweed.

Some species of gumweeds were used by the Indians and early settlers as a tonic and blood purifier. The Indians also used the resinous buds in the treatment of asthma and bronchitis.

A representative of this genus is our common Gumweed, Grindelia squarrosa (Pursh) Dunal. This erect, much-branched biennial or perennial grows 8 to 24 inches high from a woody tap root. The stems are smooth, and the alternate, stalkless

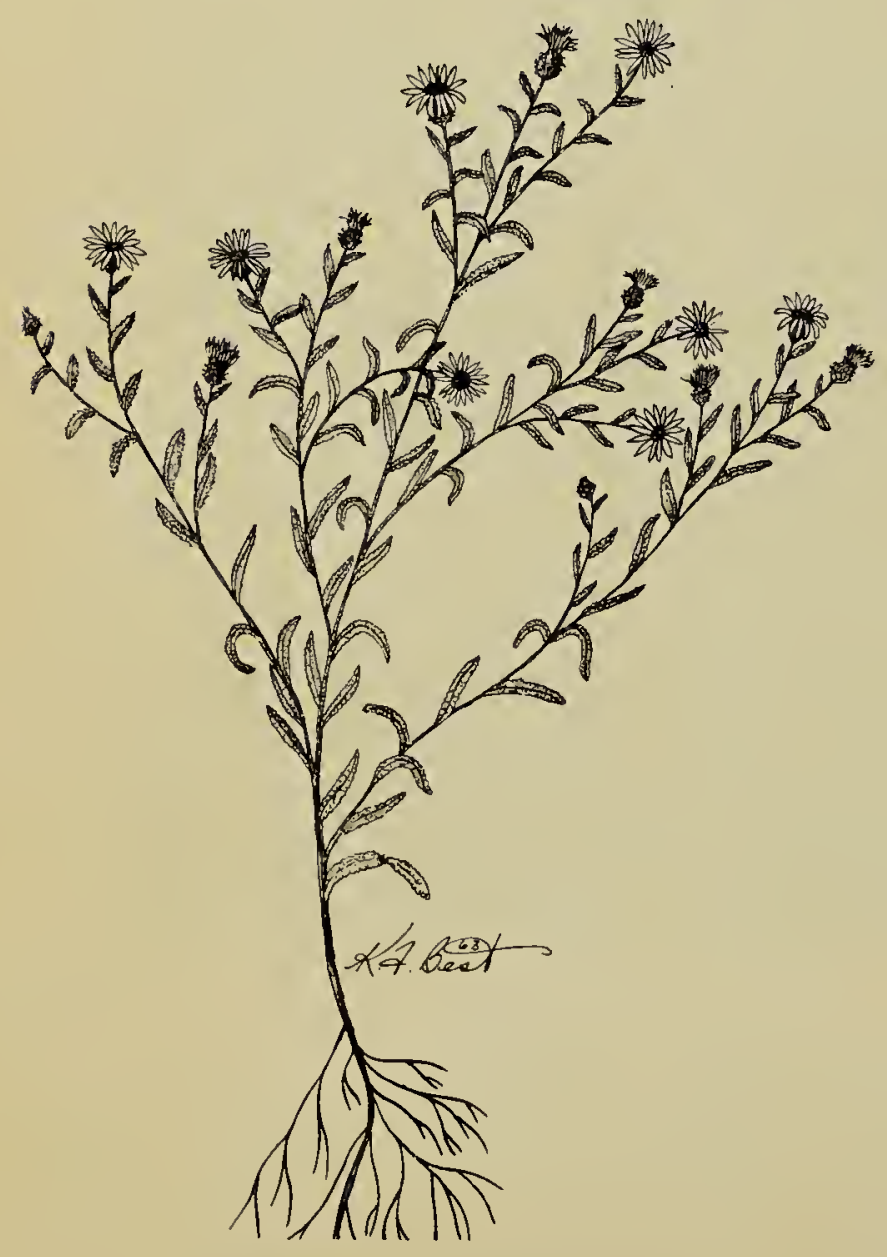

Fig. 1. Gumweed leaves are from $1 / 2$ to $1 \frac{1 / 2}{2}$ inches long, oblanceolate in outline, hairless and nave fine close teeth. The flower heads are $3 / 4$ to $11 / 4$ inches across and are borne in large numbers at the ends of the stems. Ray florets are bright yellow: The bracts overlap like shingles and are very gummy and sticky. The seeds are achenes with two or three awns.

Commonly found on the dry prairie, roadsides and on dry rocky or gravelly sites, gumweed is also frequently found on saline flats and slough margins across the southern prairies. Despite moderate abundance in some areas, gumweed has little forage value and is relatively unpalatable to all classes of livestock. Local abundance often indicates overgrazing of pastures.

The Broomweeds are also known as snakeweeds, matchweeds, turpentine-weeds and yellow top. The Mexicans call them yerba-de-vibora and coyaye. The genus was named Gutierrezia after Pedro Gutierrez, a correspondent of the Madrid Botanical Grarden. There are around 25 species of Gutierrezia, all confined to the New World. Ten of these occur in the western United States and Canada.

Common broomweed (Gutierrezia diversifolia Greene), is a manystemmed perennial growing from four to eight inches in height from a deep, woody tap root. The numerous leaves, are without stalks, entire margined, narrowly linear and from $1 / 2$ to $1 \frac{1 / 2}{2}$ inches long. The many small flowers are about $1 / 8$ inch high and occur in close clusters at the ends of the branches.

Generally inhabiting dry prairie lands, well drained sandy, gravelly or clay soils, it is also able to grow on heavy clay soils. Although this species is generally considered worthless as forage, it does play an important role on depleted ranges in protecting them against wind and water erosion. Owing to its unpalatability, it tends to increase with overgrazing. The narrow leaves and the deep roots make it extremely drought tolerant. It is said that the Indians used this plant as a broom, hence the common name. 


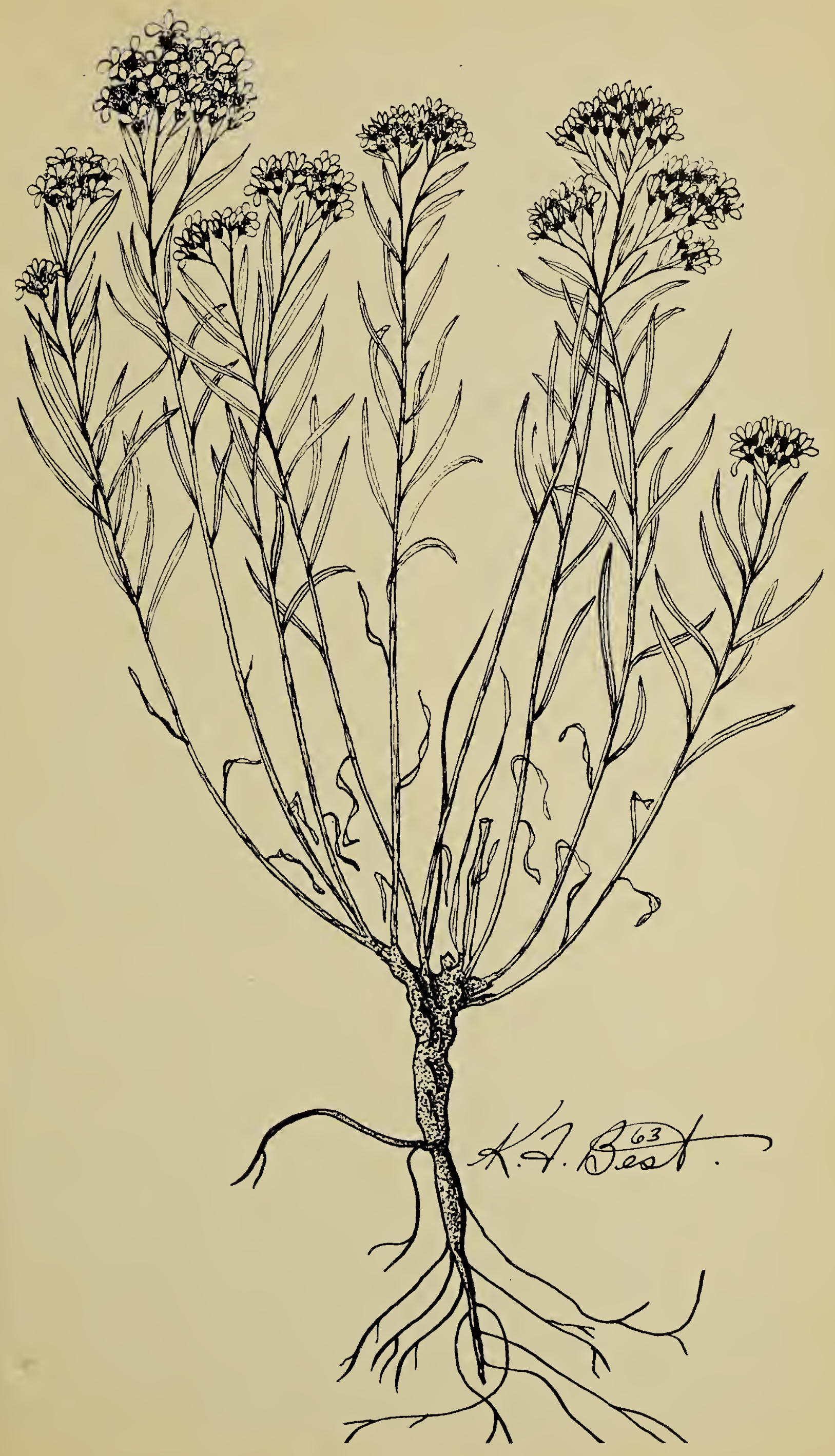

Fig. 2. Broomweed 